\title{
МОНОМЕРЫ ШЕЛЛАКА - ПЕРСПЕКТИВНЫЕ СТРОИТЕЛЬНЫЕ БЛОКИ ДЛЯ СИНТЕЗА НОВЫХ ФИЗИОЛОГИЧЕСКИ АКТИВНЫХ ВЕЩЕСТВ
}

\author{
С.В. Афанасьева, А.В. Семаков, С.Г. Клочков \\ Институт физиологически активных веществ Российской академии наук, \\ 142432, Россия, Черноголовка, Северный проезд, д. 1.
}

DOI: 10.19163/MedChemRussia2021-2021-294

E-mail: svafa@ipac.ac.ru

Шеллак - коммерчески доступная смола природного происхождения. Основной ее компонент - полимер, который представляет собой полиэфир из чередующихся остатков линейных алифатических кислот и сесквитерпеновых кислот с углеродным скелетом типа кедрана. Больший интерес как субстраты для синтеза новых соединений представляют именно сесквитерпеновые кислоты. Несмотря на доступность шеллака как сырья, его сесквитерпеновые кислоты-мономеры никогда ранее не использовались как строительные блоки или скаффолды для синтеза новых биологически активных соединений. Небольшая молекулярная масса, наличие сразу нескольких разнородных функциональных групп (первичные и вторичные спирты, алкеновая, карбоксильная и альдегидная группы), жесткая каркасная структура молекулы, умеренная липофильность, отсутствие собственной цитотоксичности чистых сесквитерпеновых мономеров делают их перспективными веществами для использования в качестве строительных блоков для синтеза на их основе новых соединений. Процесс разделения кислот шеллака на индивидуальные компоненты удобнее проводить путем хроматографии не в чистом виде, а виде их метиловых эфиров. Исходные кислоты затем регенерируют также щелочным гидролизом из чистых эфиров.

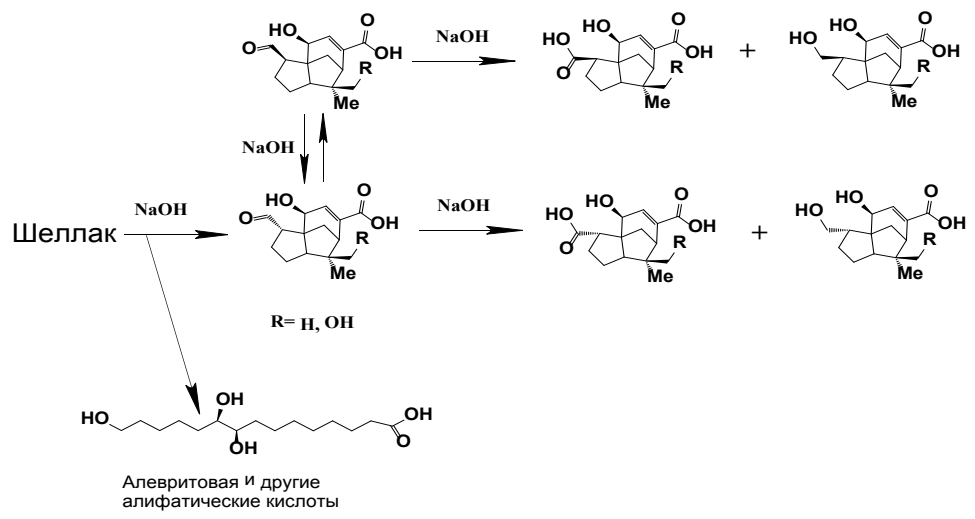

Содержание продуктов гидролиза зависит от времени и температуры. При длительном гидролизе в смеси не наблюдается альдегидных кислот из-за их полного диспропорционирования. 